\title{
PENTINGNYA KEMASAN TERHADAP PENJUALAN PRODUK PERUSAHAAN
}

\author{
Masayu Endang Apriyanti \\ Program Studi Desain Komunikasi Visual \\ Fakultas Bahasa dan Seni Universitas Indraprasta PGRI \\ email: masayuendangapriyanti@gmail.com \\ Diterima: Februari 2018; Disetujui: Maret 2018; dipublikasikan: April 2018
}

\begin{abstract}
ABSTRAK
Penelitian ini bertujuan untuk mengetahui peran kemasan dimata konsumen yang akan meningkatkan atau menurunkan penjualan produk suatu perusahaan, Karena sesungguhnya tampilan kemasan yang menarik akan memberi kesan tersendiri bagi para konsumen dalam menentukan keputusannya untuk membeli atau tidak membeli suatu produk. Metode penelitian dilakukan secara deskriptif yang bersifat survey langsung pada kelompok-kelompok masyarakat tertentu, studi perpustakaan dan literatur. Hasil dari penelitian ini membuktikan bahwa tampilan kemasan yang sangat menarik bagi konsumen akan meningkatkan penjualan produk perusahaan.
\end{abstract}

Kata kunci : Kemasan, Penjualan Produk, Perusahaan

\section{ABSTRACT}

This research aims to determine the role of packaging in the eyes of consumers who can increase or decrease sales of company products. Because the attractive display of packaging will give the impression for consumers then they will decide ehether to buy or not to buy that products. This reseach methode is done descriptively direct survey in community groups, library studies and literature. The results of this study prove that the appearance of a very attractive packaging will increase of company products.

Keywords : Packaging, product sale, company

\section{PENDAHULUAN}

Sesungguhnya tampilan kemasan suatu produk memberikan pengaruh dimata konsumen, karena melalui kemasan tersebut konsumen mendapatkan pesan dari isi produk didalamnya, baik melalui tulisan informasi yang tertera dikemasan tersebut, maupun dari tampilan suatu kemasan yang memberikan citra atau kesan tersendiri dimata konsumen sehingga konsumen dapat memutuskan untuk membeli atau tidak membeli suatu produk. Kunci utama untuk membuat sebuah desain kemasan yang baik adalah kemasan tersebut harus simple (sederhana), fungsional dan menciptakan respons emosional positif yang secara tidak langsung berkata : "belilah saya". Kemasan harus dapat menarik perhatian secara visual, emosional dan rasional. Sebuah desain kemasan yang bagus memberikan sebuah nilai tambah terhadap produk yang dikemasnya.(Christine Suharto Cenadi, 2000, Jurnal Nirmana, Vol.2 No.1 Hal.92). berarti 
kemasan harus memberikan kesan terbaik pada pandangan pertama konsumen, karena kesan terbaik itulah yang akan sangat mempengaruhi keputusan konsumen untuk membeli atau meninggalkan produk yang ditawarkan oleh perusahaan tertentu.

Dikarenakan beberapa hal, seperti kurangnya ketersediaan dana yang harus dialokasikan dalam program promosi (termasuk didalamnya desain kemasan), kurang fahamnya pihak manajemen perusahaan akan pentingnya tampilan kemasan bagi produk-produk yang dihasilkannya, atau kurang kreatif dan inovatifnya personil dibagian promosi/manajemen pemasarannya, maka tidak semua perusahaan mampu menampilkan kemasan produknya semenarik mungkin, sehingga perusahaan tersebut hanya mengemas produk seadanya atau biasa saja, Padahal, sudah sepatutnya perusahaan mengemas produknya dengan kemasan terbaik bahkan secara periodik melakukan inovasi atas kemasan-kemasan yang ditampilkannya, karena hal tersebut dapat mempengaruhi minat beli konsumen secara luas. Padahal, untuk meningkatkan penjualan produk didalam dunia usaha dimana saat ini penuh persaingan ketat, maka perusahaan dituntut untuk mampu kreatif dalam banyak hal, baik dalam menghasilkan produknya maupun dalam memikat hati konsumen agar tertarik untuk membeli output yang dihasilkannya yaitu salah satunya dengan melalui tampilan kemasan secara fisik maupun tampilan iklan elektronik dan iklan cetak atas produk tersebut.

"Design is to design a design to produce a design" (John Heskett, 2004) yang memberikan pengertian bahwa ada tiga ranah dalam cakupan pengertian desain yaitu (1). Metode Perancangan mengenai prosedur dan proses (2). Konsep nilai yang terkandung didalam konten desain mengenai identitas dan makna (3). Desain sebagai artefak yang mencakup media dan fungsi desain (Dr, Agung Eko Budiwaspada, 2017, dalam Seminar Nasional Desain dan Media, ISBN No. 978-602-50181-1-4, hal 6). Jika dilihat dari sisi perusahaan, maka desain kemasan yang diciptakan untuk membalut output yang dihasilkan lebih mengarahkan kepada pentingnya desain kemasan yang memberikan arti konsep nilai yang mencerminkan suatu identitas dan makna, dimana desain kemasan tersebut merujuk pada identitas perusahaan yang bersangkutan (apakah perusahaan memiliki posisi sebagai pemimpin pasar, sebagai pengikut pasar atau sebagai pecundang pasar), bagaimana kekuatan perusahaan tersebut dalam kreativitas, inovasi dan menggunakan daya saingnya dengan baik, serta bagaimana desain kemasan tersebut mampu mewakili perusahaan dalam menyampaikan isi pesan (makna) dari tampilan yang disajikan baik melalui media desain kemasan dalam suatu iklan (cetak \& elektronik), desain kemasan yang dibuat untuk membalut produk yang dihasilkan perusahaan (desain kemasan tersebut bisa diaplikasikan untuk melekat pada kemasan primer, sekunder maupun tertier) yang dapat bermakna bahwa perusahaan sangat perduli / perhatian kepada konsumennya dengan memberikan kemewahan pada setiap produknya yang sudah langsung dapat dilihat mulai dari kemasannya, atau mungkin juga sebagai brand image suatu perusahaan ternama yang memberi kesan makna bahwa semua disajikan secara istimewa, karena ketersediaan dana yang ada, atau mungkin juga untuk berbagai alasan lainnya karena masingmasing perusahaan pasti memiliki alasan tersendiri dalam membuat setiap desain kemasan untuk produk yang dihasilkannya.

Kreativitas bentuk tampilan kemasan kian hari terus berkembang hingga saat ini banyak sekali muncul tampilan kemasan unik dan berbeda dengan beragam bentuk dan bahan sebagai representasi produk di dalamnya, dimana kemasan sudah merupakan salah satu media dalam mempromosikan produk, karena kemasan yang baik akan merepresentasikan produk di dalamnya. Pengemasan adalah kegiatan merancang dan memproduksi wadah atau bungkus sebagai sebuah produk (Kotler \& Keller, 2009:27), namun sesungguhnya kemasan bukan hanya pembungkus saja, karena kemasan memberikan kesan mendalam pada pandangan pertama yang membuat konsumen jatuh hati pada suatu produk yang kemudian memutuskan untuk membeli atau membatalkan pembelian.

Kemasan adalah salah satu bidang dalam desain komunikasi visual yang mempunyai banyak tuntutan khusus karena fungsinya yang langsung berhadapan dengan konsumen, antara lain tuntutan tekhnis, kreatif, komunikatif dan pemasaran yang harus diwujudkan kedalam 
bahasa visual (Azhari Amri, 2016 : 165). Sebenarnya Kemasan itu memiliki 2 fungsi, yaitu Fungsi Protektif, yang berkenaan dengan proteksi produk, perbedaan iklim, prasarana transportasi, dan saluran distribusi yang semua berimbas pada pengemasan. Dengan pengemasan protektif, para konsumen tidak perlu harus menanggung risiko pembelian produk rusak atau cacat dan Fungsi Promosional, bahwa kemasan berperan sebagai sarana promosional, dimana perusahaan mempertimbangkan preferensi konsumen menyangkut warna, ukuran, dan penampilan. Pada saat ini, sebaiknya agar tetap eksis didunia usaha maka perusahaan harus mampu memberikan kemasan terbaik dan menarik atas produknya agar dapat memikat hati para konsumennya sehingga mampu memenangkan persaingan yang sangat ketat.

Pada umumnya penjualan merupakan usaha konkrit memindahkan produk, baik barang ataupun jasa, dari produsen kepada konsumen sehingga mampu memberikan keuntungan/laba. Didalam penjualan harus dilakukan pengelolaan dan kerjasama yang baik antara pengusaha, produktivitas perusahaan, pekerja dalam perusahaan, para supplier, agen, pedagang dan tenaga pemasaran. Sehingga jika semua pihak bersinergi kuat maka penjualan yang efektif dan effisien dapat terlaksana dengan baik dan memberikan hasil memuaskan sesuai target yang diharapkan.perusahaan.

Produk adalah hasil proses produksi yang dilakukan produsen atau perusahaan, kemudian dijual kepada konsumen yang membutuhkan baik untuk memenuhi keperluan sehari-hari, memenuhi kebutuhan pokok maupun memenuhi keinginan / gengsi / kepuasan gaya hidup konsumen, dimana hasil penjualan produk tersebut merupakan pendapatan / penghasilan / penerimaan arus kas masuk untuk perusahaan yang bersangkutan. Pada umumnya sebagian besar konsumen lebih menyukai produk yang harganya relatif murah tapi memiliki kualitas yang baik dimana Produk yang dihasilkan perusahaan dapat berupa barang maupun jasa sesuai kebutuhan para konsumennya.

Pelaksanaan penjualan produk setiap bulan, apakah sebuah perusahaan mampu atau tidaknya mencapai target akan sangat berpengaruh terhadap kesuksesan maupun kegagalan eksistensi kelangsungan hidup perusahaan, karena jika penjualan terus menerus tidak mencapai taget akan berpengaruh pada keterhambatannya produksi dan operasional perusahaan sehingga dapat menciptakan suatu kegagalan, karena itu pelaksanaan penjualan produk ini harus dilaksanakan sebaik mungkin salah satunya dalam menarik minat konsumen agar membeli produk yang kita tawarkan, yaitu bisa dengan cara menciptakan tampilan kemasan yang menarik agar dapat memikat hati konsumen untuk membeli produk yang perusahaan tawarkan.

Perusahaan adalah suatu badan usaha yang melakukan kegiatan ekonomi, bertujuan menghasilkan barang/jasa, terletak di suatu bangunan fisik pada lokasi tertentu, dan mempunyai catatan administrasi tersendiri mengenai produksi, struktur biaya serta ada seorang atau lebih yang bertanggung jawab atas resiko bisnis / usaha. Perusahaan adalah pihak yang mengelola sumber daya yang ada dan memprosesnya sehingga menghasilkan output untuk memenuhi kebutuhan tak terbatasnya para konsumen. Ada banyak jenis perusahaan yang berbeda latar belakang pendiriannya, visi misi dan tujuan perusahaannya dan sebagainya, namun secara garis besar tujuan perusahaan adalah mendapatkan keuntungan untuk mempertahankan eksistensi usahanya lalu mengembangkannya untuk terus maju dan sukses.

\section{METODE}

Penelitian ini menggunakan pendekatan kualitatif yaitu pemahaman yang berdasarkan pada metodologi dengan menyelidiki suatu fenomena sosial dan masalah manusia. Didalam penelitian ini, metode yang digunakan peneliti adalah metode deskritif yang bersifat follow up study . yang memungkinkan untuk melakukan hubungan antar variabel, menguji hipotesis, mengembangkan generalisasi, dan mengembangkan teori yang memiliki validitas universal. Metode deskriptif adalah suatu metode dalam meneliti status sekelompok manusia, objek, 
kondisi, sistem pemikiran ataupun suatu kelas peristiwa pada masa sekarang. Tujuan dari penelitian deskritif ini adalah untuk membuat deskripsi, gambaran atau lukisan secara sistematis, faktual dan akurat mengenai fakta, sifat serta hubungan antar fenomena yang diselidiki ( Sugiyono, 2007 : 11 ). Beberapa fenomena yang dilihat hubungannya adalah Peran kemasan terhadap peningkatan penjualan produk perusahaan. Metode pengumpulan data dalam penelitian ini adalah dengan mewawancarai kelompok-kelompok masyarakat, studi perpustakaan dan literatur.

\section{HASIL DAN PEMBAHASAN}

Setiap Perusahaan pasti menginginkan mampu eksis dan terus tumbuh berkembang maju dalam menjalankan usahanya, karena itulah perusahaan berusaha melakukan berbagai strategi agar mampu menghadapi persaingan usaha yang ada didunia usaha. Salah satu strategi pemasaran yang dapat perusahaan lakukan adalah menciptakan kemasan produk yang terbaik dan menarik untuk membalut produk yang dihasilkannya. Kemasan baik dari sisi desain maupun dari sisi tampilannya, sebaiknya direncanakan seefektif dan efisien mungkin, karena pemilihan desain dan realisasi wujud tampilan kemasan tersebut akan cukup memakan biaya yang tidak sedikit yang pada akhirnya tentu akan mempengaruhi perubahan harga pokok produksi dan mempengaruhi harga jual yang harus dibayar oleh konsumen atas suatu produk perusahaan. Sehingga langkah bijaknya adalah perusahaan seharusnya mampu memberikan desain dan tampilan kemasan produk terbaik dan menarik dengan tetap memperhatikan agar biaya yang dikeluarkan dapat diatur seminimal mungkin agar nanti harga produk berkemasan terbaik tersebut dapat dijual dengan harga terjangkau.

Kemasan merupakan pemicu karena fungsinya langsung berhadapan dengan konsumen, karenanya kemasan harus dapat memberikan impresi spontan yang mempengaruhi tindakan positif konsumen di tempat penjualan (christine suharto cenadi, vol. 2 No. 1, 2000)

Ada beberapa hal yang dapat dilakukan dalam menciptakan kemasan produk terbaik yang dapat memikat hati konsumen yaitu dengan membuat kemasan produk yang : Unik, agar terkesan lebih menarik dan beda dibandingkan produk lain dengan jenis usaha sama. Sesuaikan Desain kemasan dengan produk, misalkan saja produk yang akan ditawarkan adalah produk kuliner, maka desain kemasan dan tampilannya bisa berupa gambar atau animasi rasa buah atau sayur yang ditawarkan produk kuliner tersebut, Buat Kemasan berbagai ukuran dan bentuk agar banyak ragam konsumen mulai partai kecil dapat membeli produknya sesuai kebutuhan, karena bentuk dan ukuran kemasan suatu produk akan mempengaruhi harga produk tersebut yang pada akhirnya akan mempengaruhi penjualan karena kemampuan beli para konsumennya. Buatlah kemasan yang dapat didaur ulang agar biayanya tidak mahal, ramah lingkungan dan juga dapat ikut berperan menjaga kelestarian lingkungan dan dunia. Buat kemasan dengan berbagai karakter konsumen agar dapat disesuaikan dengan target dan sasaran pasar.

Dalam penelitian yang dilakukan Masayu Endang Apriyanti, Agung Zainal Muttakin, Herliyana, Prosiding Seminar Nasional Desain Komunikasi Visual, 22 Oktober 2017, "Pengaruh Desain Kemasan Sabun Mandi Terhadap Persepsi Makna Kecantikan Wanita", ditemukan hasil penelitian secara kuantitatif bahwa kemasan memberikan pengaruh signifikan terhadap makna kecantikan bagi wanita, dengan perhitungan dalam sumbangan efektif bahwa kemasan sabun dove memberikan sumbangan efektif sebesar 16,73\%, kemasan sabun lux memberikan sumbangan efektif sebesar 68,28 \% dan kemasan sabun shinzhui memberikan sumbangan efektif sebesar 14,98 \% (Seminar Nasional Desain dan Media, ISBN No. 978-60250181-1-4 hal. 78), artinya konsumen saat ini semakin cerdas dan mengerti tentang produk yang ingin dipilih untuk dibelinya, konsumen dapat mengenal dan mengerti dengan baik bahwa desain kemasan yang tersaji (dalam hal ini mengambil contoh 3 sample produk, yaitu sabun dove lux dan shinzhui) mampu mewakili identitas, pesan dan makna yang ingin disampaikan 
oleh produsen kepada konsumen, dalam hasil disini kemasan sabun lux memberikan sumbangan efektif terbesar dibanding yang lainnya, artinya para konsumen mengenal sabun lux melalui kemasan yang ditampilkan dengan sangat baik, dimana kemasan lux ini mewakili identitas perusahaan Unilever sebagai perusahaan yang besar, bonafid, kuat dan cukup memimpin pasar dalam hal menghasilkan produk perawatan kecantikan bagi wanita, kemasan lux ini memberikan pesan bahwa produk yang ditawarkan adalah yang terbaik mulai dari bahan baku yang digunakan, proses produksi yang dilakukan, pengemasan dan pengirimannya mencerminkan bahwa perusahaan hanya memberikan yang terbaik atas layanan dan kualitas produknya, dan tampilan kemasan lux ini juga memberikan makna bagi kecantikan wanita bahwa dengan menggunakan produk lux wanita merasa dimanjakan dan dirawat kecantikannya, konsumen menilai bahwa merawat kecantikan bagi wanita tidak harus pergi kesalon mahal atau harus membeli dan menggunakan produk-produk kecantikan bermerek terkenal dari luar negeri, karena cukup dengan menggunakan produk lux yang memberikan kesan produk mewah dan berkualitas dengan harga relatif terjangkau dapat menjaga kecantikan para wanita secara alami.

Dari penelitian ini dapat dilihat bahwa desain kemasan memiliki peran penting dalam mempengaruhi keputusan konsumen untuk membeli suatu produk, artinya semakin baik kemasan yang ditampilkan oleh perusahaan akan mempengaruhi semakin banyaknya konsumen yang memutuskan untuk memilih / membeli produknya, sehingga dalam membuat desain kemasan perusahaan harusnya bersungguh-sungguh dan tidak semaunya sendiri, yang tentunya juga harus diimbangi dengan kemampuan perusahaan dalam hal dana yang akan digunakan untuk dialokasikan pada desain kemasan ini (karena desain kemasan secara tidak langsung juga berperan untuk mempromosikan produk perusahaan).

Dalam penelitian Angelina Diah Kusumasari dan Supriono pada Jurnal Administrasi Bisnis (JAB) Vol. 49 No.2, 2017 "Pengaruh Desain Kemasan Produk dan Daya Tarik Iklan Terhadap Brand Awareness Serta Dampaknya Pada Keputusan Pembelian Wardah Exclusive Matte Lip Cream", hasil pembahasan penelitian kuantitatifnya membuktikan bahwa koeffisien jalur desain kemasan produk terhadap keputusan pembelian produk sebesar 0,320 artinya setiap peningkatan desain kemasan produk sebesar 1 satuan, maka keputusan pembelian produk akan meningkat sebesar 0,320 kali dan kontribusi desain kemasan produk terhadap keputusan pembelian produk sebesar $26 \%$ artinya bahwa perubahan sebesar $26 \%$ pada keputusan pembelian produk disebabkan oleh perubahan desain kemasan produk (JAB, Vol. 49 No. 2, Hal. 107).

Dilihat berdasarkan hasil-hasil penelitian diatas, semuanya menunjukan bahwa desain kemasan suatu produk sangat berperan dalam mempengaruhi keputusan konsumen untuk membeli atau membatalkan pembelian suatu produk tertentu, sehingga memang sudah selayaknya produsen lebih memperhatikan dan kreatif lagi untuk menampilkan desain kemasan yang menarik dan terbaik untuk para konsumennya.

Penjualan adalah pemindahan hak milik atas barang atau pemberian jasa yang dilakukan penjual kepada pembeli dengan harga yang telah disepakati (Freddy Rangkuti, 2009:57). Salah satu cara meningkatkan kuantitas penjualan adalah membalut produk-produknya dengan desain kemasan yang fungsinya bukan sekedar mewadahi dan melindungi produk dari kerusakankerusakan, sehingga lebih mudah disimpan, diangkut dan dipasarkan namun juga memberikan banyak kesan yang menarik, nyaman dan prestise bagi pembelinya. Karena dengan desain kemasan yang menarik maka konsumen akan lebih tertarik untuk membeli produk suatu perusahaan tertentu sehingga hal tersebut meningkatkan penjualan produk bagi perusahaan.

Penjualan sangat penting bagi perusahaan, karena melalui penjualan tersebutlah perusahaan mendapatkan keuntungan/kerugian sebagai sumber yang membentuk nilai keseluruhan perusahaan, arus pendapatan yang masuk, kelancaran operasional perusahaan karena tingginya hasil penjualan tersebut membuat Perusahaan mampu beroperasional dengan lancar, mampu melakukan produksi dengan baik dan teratur, dapat menambah modal untuk mengembangkan usaha, dapat membayar gaji karyawannya tepat waktu dan memenuhi berbagai kewajibannya dengan baik, itu semua dampak dari hasil penjualan yang baik, lancar dan tinggi. 
Perusahaan menghasilkan produk terbaik lalu menjual dengan harga terjangkau pada konsumen, dan konsumen membeli produk tersebut sesuai kebutuhannya, maka sesungguhnya baik Perusahaan maupun konsumen sama-sama mendapatkan keuntungan, dimana perusahaan mendapat laba untuk kelancaran produktivitas perusahaan, dan konsumen mendapatkan produk yang dibutuhkannya itu dengan harga terjangkau.

Penjualan produk yang ditawarkan perusahaan agar terus meningkat, haruslah memperhatikan beberapa faktor, diantaranya yaitu : (1).Perusahaan harus mengetahui keinginan dan kebutuhan konsumen agar dapat menciptakan produk sesuai kebutuhan pasar dengan harga terjangkau. (2).Perusahaan harusnya menetapkan pangsa pasar, agar dapat menentukan dimana barang barang yang dibutuhkan akan dipasarkan atau dijual (3).Faktor modal, dapat meningkatkan proses produksi, juga bisa digunakan untuk mengembangkan usaha yang akan menghasilkan tambahan laba. (4).Persaingan, hadapilah dengan percaya diri dengan penuh kreativitas dan inovatif sehingga dapat meningkatkan efektifitass dan efisiensi dalam produktivitas. (5).Berikan layanan purna jual, agar konsumen dapat menyampaikan keluhan atau saran guna peningkatan kualitas produk perusahaan kita, misalkan saya pelayanan purna jual, seperti perbaikan, perawatan, pengantaran barang, dan pemberian garansi, pemberian hadiah, kampanye, peragaan, dan iklan.

Dalam menciptakan penjualan dan pemasaran yang baik didalam perusahaan, harus dilaksanakan dengan strategi penjualan yang baik, yang tentunya itu bukanlah hal instan, butuh waktu untuk proses agar produk dapat diterima pasar dengan baik dan perusahaan mendapatkan respon sesuai harapan dan target yang ditetapkan.

Strategi meraih sukses salah satunya adalah menjaga hubungan baik dengan pelanggan yang tujuannya adalah memberikan pelayanan istimewa kepada pelanggan, sehingga pelanggan merasa puas dan menjadi pelanggan yang loyal (Freddy Rangkuti, 2015 ; 161).

Kepuasan pelanggan adalah tingkat perasaan konsumen setelah membandingkan pelayanan yang dirasakan dengan harapannya, yaitu : (1) Apabila pelayanan dibawah harapan maka pelanggan akan kecewa (2) Jika pelayanan sesuai harapan maka pelanggan akan puas (3) Jika pelayanan melebihi harapan pelanggan maka itulah kepuasan prima (Andri Feriyanto \& Endang S, $2015: 180$ ).

Hubungan yang baik antara perusahaan dengan konsumen, tingkat kepuasan dan loyalitas adalah hal penting yang dapat mempertahankan jumlah / tingkat penjualan produk-produk perusahaan, karena hal tersebut secara tidak langsung mengikat konsumen untuk selalu membeli semua produk yang ditawarkan suatu perusahaan tertentu, namun harus diiingat juga bahwa sekarang persaingan sangatlah ketat dan perubahan dunia usaha bergerak dengan sangat cepat, sehingga sebaiknya perusahaan terus menerus meningkatkan kualitas output yang dihasilkannya, tetap menjaga harga agar terjangkau bagi konsumen diberbagai lapisan dan menjaga hubungan dengan sangat baik pada para konsumennya, agar perusahaan dapat terus eksis dan kuat bertahan dalam ketatnya persaingan.

Perusahaan adalah bagian tekhnis dari kesatuan organisasi, modal dan tenaga kerja yang bertujuan menghasilkan barang atau jasa, dengan demikian perusahaan adalah tempat berlangsungnya proses produksi (Rusdiana, 2015 : 240). Dilihat dari bentuk hukum, maka macam-macam jenis perusahaan adalah perusahaan perorangan, firma, CV, dan PT. Perusahaan merupakan salah satu pelaku ekonomi yang memiliki peran penting dalam kegiatan ekonomi, yaitu : (1). Membeli faktor-faktor produksi seperti bahan baku, tenaga kerja, modal, dan pengusaha (kewirausahaan). (2). Mengelola \& mengombinasikan faktor-faktor produksi untuk memproduksi barang dan jasa., dimana perusahaan berperan sebagai produsen. (3). Menjual barang dan jasa yang sudah dihasilkan kepada rumah tangga, pemerintah, masyarakat luar negeri atau kepada ketiga-tiganya. (4). Bertanggung jawab terhadap kesejahteraan karyawan dan masyarakat sekitar.

Demi kesuksesan usahanya, setiap perusahaan pasti melakukan strategi terbaiknya untuk mempertahankan kelangsungan hidup kegiatan produktivitasnya, dimana sejatinya ada keterkaitan erat yang saling memberikan manfaat positif antara kegiatan ekonomi, produksi, 
penjualan dan operasional perusahaan dengan pihak pekerja, supplier, konsumen dan pemerintah. Perusahaan besar dan kecil yang mampu menciptakan beragam output guna pemenuhan kebutuhan pasar, sejatinya mereka juga berperan memperbaiki kualitas hidup para pegawainya, karena dari hasil laba yang didapat, perusahaan membayar gaji karyawan dimana dengan gaji tersebut pegawai memenuhi beragam kebutuhan ekonomi keluarganya, demikian juga pemerintah mendapatkan pemasukan pajak, devisa, be cukai dan sebagainya dari perusahaan setiap bulannya, dimana dengan pemasukan tersebut pemerintah dapat meningkatkan kualitas hidup pelayanan publik dengan pembangunan infrastruktur dan sebagainya.

Dari berbagai kegiatan yang harus dilakukan perusahaan untuk mempertahankan kelangsungan hidupnya, salah satu yang terpenting adalah faktor penjualan, berangkat dari penjualan, berarti perusahaan harus mampu menarik minat konsumen untuk membeli produkproduk yang dihasilkannya, untuk menarik minat konsumen berarti salah satu usaha yang dapat dilakukan perusahaan adalah menciptakan desain dan tampilan kemasan menarik, agar ketika konsumen melihat pada pandangan pertamanya mereka menangkap isi pesan terbaik dari produk yang ditawarkan melalui tampilan kemasan suatu produk tersebut sehingga mereka suka lalu tertarik untuk membelinya.

Semakin menarik kualitas tampilan kemasan dan isi produk maka semakin banyak konsumen yang membelinya, sehingga penjualan perusahaan akan meningkat secara signifikan. Melalui tampilan suatu kemasan, konsumen dapat mencoba memahami isi pesan yang disampaikan melalui kemasan produk tertentu, dan pada umumnya kemasan selalu memberikan dampak yang baik dan berarti bagi konsumen, bahkan konsumen rela membayar lebih banyak / lebih mahal untuk produk yang berkemasan lebih cantik, menarik, berbeda dan unik dari produk sejenis.

\section{SIMPULAN}

Pada dunia usaha saat ini dengan situasi persaingan yang semakin ketat, menuntut para pengusaha yang ingin terus sukses agar kreatif dalam berbagai hal, salah satunya adalah menciptakan tampilan kemasan semenarik mungkin untuk membungkus produk yang dihasilkan dan siap ditawarkan kepasar, agar banyak konsumen yang berminat membeli semua produk yang ditawarkan perusahaan.

\section{SARAN}

1. Pengusaha dan perusahaan sebaiknya mempersiapkan budget tertentu untuk menciptakan tampilan kemasan yang menarik baik kemasan secara fisik yang membungkus produknya maupun tampilan yang dikemas dalam mengiklankan produknya di media cetak maupun media elektronik, karena sesungguhnya kemasan yang ditampilkan untuk setiap produk yang akan dijualnya, bukan hanya menjadi ajang promosi melainkan juga mewakili citra perusahaan yang pada akhirnya dapat meningkatkan penjualan dan omzet yang didapatkan oleh perusahaan.

2. Karyawan Perusahaan, mulai dari penentu keputusan dan para manajer pemasaran sampai pada bagian marketing hendaknya lebih kreatif inovatif dan peka terhadap situasi kondisi yang ada dipasar, semua pihak terkait hendaknya bersinergi memberikan kreasi kemasan dan produk terbaik dan menarik untuk meningkatkan daya tarik konsumen dan kepuasan konsumen dalam mengkonsumsi barang / jasa yang kita tawarkan yang pada akhirnya sangat berpengaruh terhadap peningkatan penjualan, penerimaan pendapatan, eksistensi dan keberlangsungan hidup perusahaan. 
3. Konsumen, hendaknya tetap harus bijak dan selektif dalam memilih produk yang akan dibeli, juga jangan hanya melihat dari kemasan, karena tidak semua kemasan terbagus yang membalut produk tersebut adalah yang paling berkualitas sesuai kebutuhan konsumen dan kemampuan daya belinya, karena biasanya, kemasan suatu produk semakin mewah, berkualitas dari bahan-bahan terbaik akan mempengaruhi tingginya harga produk tersebut.

\section{DAFTAR RUJUKAN}

Sugiyono, (2007), "Metode penelitian pendidikan, pendekatan kuantitatif, kualitatif dan $\boldsymbol{R} \& \boldsymbol{D}$ ”, Bandung, Alphabeta.

Azhari Amri, (2016), "Model penelitian desain komunikasi visual”, Bekasi, PT. Cakra Press.

Masayu Endang Apriyanti, Agung Zainal Muttakin, Herliyana, Seminar Nasional Desain dan Media, 22 Oktober 2017, "Pengaruh desain kemasan sabun mandi terhadap persepsi makna kecantikan wanita”, Jakarta, Universitas Indraprasta PGRI.

Kotler dan Keller. (2009), “Manajemen pemasaran. jilid I. Edisi ke 13”. Jakarta: Erlangga.

Freddy Rangkuti, (2009). "Strategi promosi yang kreatif dan analisis kasus". Jakarta: PT Gramedia Pusataka Utama.

Freddy Rangkuti, (2015). "Personal SWOT analysis". Jakarta: PT Gramedia Pusataka Utama.

Andri Feriyanto dan Endang Shyta Triana, (2015), "Komunikasi bisnis - strategi dalam mengelola bisnis”, Yogyakarta, Mediatera, PT. Pustaka Baru.

Rusdiana, (2015), Kewirausahaan - teori dan praktik”, Bandung, PT. Pustaka Setia.

Agung Eko Budiwaspada, Seminar Nasional Desain dan Media, 22 Oktober 2017, "Desain dan media sebagai instrument nation branding”, Jakarta, LPMP, Unindra.

John Heskett, (2002), "Design a very short Introduction”, Oxford University Press Inc., Newyork.

Christine Suharto Cenadi, (2000), “Peranan desain kemasan dalam dunia pemasaran”, Jurnal Desain Komunikasi Visual Nirmana, Vol. 2 No. 2, ISSN 0215-0905.

Angelina Diah Kusumasari dan Supriono, (2017), "Pengaruh desain kemasan produk dan daya tarik iklan terhadap brand awareness serta dampaknya pada keputusan pembelian Wardah Exclusive Matte Lip Cream”, Jurnal Administrasi Bisnis (JAB), Vol. 49 No. 2 Agustus 2017) 